\title{
Method of Sugar Production From Arrowroot Starch: A Review
}

\author{
Enjang Rohman, Rama Tiyana*, Sarah Amelia Nur Wahidah Al Falah, Mustika Nuramalia Handayani \\ Faculty of Technology and Vocational Education \\ Universitas Pendidikan Indonesia \\ Bandung, Indonesia \\ enjangrohman81@upi.edu,*ramatiyana@upi.edu, sarahamelia14@upi.edu,mustika@upi.edu
}

\begin{abstract}
Sugar production from sugar cane, palms, and beet plants could not be able to fulfill domestic sugar need in Indonesia. Moreover, there is a shift in sugarcane as a raw material for ethanol. An alternative solution to this problem is sugar production from other sources such as starch, which is widely found in local Indonesian tubers. Arrowroot tubers (Maranta arundinacea L.) are minor tubers that have potential to be used as raw material for sugar production because they contain 19.40-20.96\% starch. The purpose of this study was to explore a method of producing sugar based on arrowroot starch. The method used was literature review. In general, the production of arrowroot starch-based sugar consists of extraction, hydrolysis, purification, and crystallization. Starch extraction can be done using wet or dry methods. Hydrolysis aims to break down starch into simple sugars which can be done by acid hydrolysis, enzymatic hydrolysis or a combination of both. Purification aims to remove impurities from sugar components through defecation, sulfitation, or carbonation methods. Crystallization aims to obtain sugar crystals which can be done by adding anti-solvent or cooling. Productivity and quality of arrowroot starch-based crystal sugar depend on the sugar production method used.
\end{abstract}

Keywords-arrowroot starch, sugar, crystallization, extraction, hydrolysis, purification

\section{INTRODUCTION}

Indonesia is targeting sugar self-sufficiency in sugar by 2024 [1]. Unfortunately, Indonesia is still the second largest sugar importer after China (2019-2020) with an import value of 4.04 billion metric tons. [2]. The four-year period is a short period to change the position of the importing country to an independent producer.

Sugar production from sugar cane, palms, and beet plants could not be able to fulfill domestic sugar need in Indonesia [3]. Moreover, the transfer of sugar cane for bioethanol production, making sugar made from sugar cane projected decreased [3]. Therefore, it is necessary to produce sugar made from raw materials other than sugar cane, for example starch which is widely contained in local Indonesian foodstuffs.
Arrowroot (Maranta arundinacea L.) is one of the minor tubers that is rarely used as a consumption material by Indonesian people [4]. Arrowroot crops have been proclaimed by the government as one of the food commodities that have priority to be developed/cultivated [5-7]. Arrowroot plants are very easy and suitable to be planted in Indonesia due to their high adaptability [5]. Arrowroot plants are able to adapt to shade (under tree stand) and on marginal land [5] without lowering the quality or characteristics of tubers [6]. Arrowroot can also be cultivated with monoculture, polyculture system [8], as well as yard plant [5]. The productivity of Arrowroot bulbs harvested at 12 months can reach \pm 36 tons /ha [9].

Arrowroot is a type of carbohydrate-producing plant with high quality $[5,10,11]$. Arrowroot contains carbohydrates with a content of up to $24.1 \%$ [12]. Most carbohydrate constituents are starch with a content of $19.40-20.96 \%$ [11]. Arrowroot starch naturally has Type II resistant starch of $2.12 \%$. and $1.7 \%$ fiber $[11,12]$. The fiber form of arrowroot starch is shorter when compared to other types of starch, so starch is easily digestible with digestibility of $84.35 \%$ [11,13]. Arrowroot also has a lower glycemic index (14) than other tubers, such as gembili (90), kimpul (95), ganyong (105), and sweet potato (179) [14]. Therefore, arrowroot can be used as food for infants, children with autism and down syndrome, as well as to prevent degenerative diseases such as diabetes and cardiac disease $[4,11,13,14]$.

Arrowroot's development potential and high carbohydrate content make Arrowroot potentially to be developed into a raw material for sugar. In general, the process of sugar production from starch through the stage of extraction, hydrolysis, purification, and crystallization $[15,16]$. The purpose of this study was to explore a method of producing sugar based on arrowroot starch.

\section{METHODS}

The method used in this study is narrative review from various sources that are relevant to the objectives. Its process consists of 3 stages, namely searching, criticizing and synthesis and writing [17]. 
Searching. Broad searches of the literature on method of Sugar Production from Arrowroot Starch focusing on articles or research reports published from 2010 to 2020 but older seminal studies may also have a role in this literature review. In addition, literature is also from any other published or unpublished studies or compilations of data using search engines such as Google and Google scholar with keyword for searching: arrowroot starch, arrowroot starch extraction, acid hydrolysis, enzymatic hydrolysis, purification, and crystallization. The exhaustive citation chasing produced more than 80 references.

Critiquing. This is a step to evaluate the references that have been accumulated. Examined abstracts of the studies to ascertain whether they included any report of method sugar production from starch. If an abstract or study did not suggest this data was reported, the study was excluded from further consideration. More than 40 of the studies were selected and retrieved and further organized into one or more of the following five major topic areas: arrowroot starch extraction, hydrolysis, purification, and crystallization.

Synthesizing and Writing. Synthesizing the available literature results from critical analysis of the varied sources and leads to a summary of knowledge on the topic. Writing is done following five major topic areas, each major is written with synthetic literature so as to answer the purpose of the study.

\section{RESULTS AND DISCUSSION}

The manufacture of sugar from arrowroot tuber through several stages, namely extraction, hydrolysis, purification and crystallization. In brief, the manufacture of sugar from arrowroot tuber is shown in Table 1.

TABLE I. MANUFACTURING OF SUGAR FROM ARROWROOT TUBER

\begin{tabular}{|l|l|l|}
\hline \multicolumn{1}{|c|}{ Stages } & \multicolumn{1}{|c|}{ Aims } & \multicolumn{1}{c|}{ Methods } \\
\hline $\begin{array}{l}\text { Arrowroot } \\
\text { Extrach }\end{array}$ & $\begin{array}{l}\text { To obtain arrowroot } \\
\text { starch }\end{array}$ & $\begin{array}{l}\text { - Wet extraction } \\
\text { - Dry extraction }\end{array}$ \\
\hline Hydrolysis & $\begin{array}{l}\text { breaking down starch } \\
\text { molecules into simple } \\
\text { components }\end{array}$ & $\begin{array}{l}\text { - Enzymatic Hyrolysis } \\
\text { - Acid Hydrolysis }\end{array}$ \\
\hline Purification & $\begin{array}{l}\text { separate impurities } \\
\text { contained }\end{array}$ & $\begin{array}{l}\text { - Defecation } \\
\text { - Sulfitation } \\
\text { - Carbonation }\end{array}$ \\
\hline Crystallization & to obtain sugar crystals & $\begin{array}{l}\text { - Adding Anti- solvent } \\
\text { - Cooling }\end{array}$ \\
\hline
\end{tabular}

\section{A. Arrowroot Starch Extraction}

The starch extraction method is divided into wet and dry extraction methods [18]. Commercially, wet extraction method results in higher-quality and purer starches compared with dry techniques, as: (1) there is high starch granular damage in dry techniques, and (2) most impurities are easily removed by water washing in wet processing. Ultimately, however, the process chosen for starch extraction is usually determined by consumer/industrial demand, availability of utilities, yield/quality considerations, and various other economic factors [19].

Wet extraction is carried out by stages of the process: peeling, washing, destruction or milling, filtering, precipitation by means of habitation or by centrifugation, drying with oven or sunlight, milling and enrichment $[4,5,11,18]$. While on dry extraction, before the tubers are crushed, the tubers are cut into smaller pieces and then dried. The peeling of arrowroot must be completely removed to prevent the starch from having an off-color and off-flavor. Replacing conventional drying methods with sunlight and using centrifugal separation can improve the color and appearance of starch [20]. Some studies have also conducted immersion with a metabisulphyte potassium solution of $1000 \mathrm{ppm}$ [20] or $0.03 \% \mathrm{~m} / \mathrm{m}$ [21] before demolition is carried out to improve yield of starch [22].

Starch levels in arrowroot tubers depend on the age of the tuber harvest $[5,8,11]$. Arrowroot that will be used for starch production should be harvested after old age (age 10-12 months) [23]. Starch yield at harvest ages 6, 8, and 10 consecutive months were $14.81 \%, 14.46 \%$ and $16.37 \%$. While the levels of amylose starch at rhizome harvest age 6,8 and 10 months consecutively $8.25 \% ; 21.26 \%$ and $40.92 \%$ [23]

\section{B. Hydrolysis}

Starch hydrolysis is a process of breaking down starch molecules into simple constituent components such as dextrins, maltotriose, maltose and glucose. The products of starch hydrolysis are generally characterized based on the degree of hydrolysis and expressed by the DE (Dextrose Equivalent) value which shows the percentage of pure dextrose in the total solids of the substrate to be hydrolyzed. The hydrolysis process can be carried out enzymatically and acidically

1) Enzymatic hyrolysis: Enzymatic hydrolysis uses enzymes which are usually sourced from plants, animals or microorganisms. Enzymatic hydrolysis can be carried out using the enzymes @-amylase, glucoamylase, and pulullanase. Hydrolysis of starch into glucose syrup through three main stages, namely gelatinization, liquefaction, and saccharification.

a) Gelatinization: Gelatinization is a pre-liquidation process. Gelatinization is the process of swelling of starch granules due to heating which breaks hydrogen bonds in starch glycoside bonds. The swelling of the granules is irreversible or cannot be returned to its original shape. Liquidation without prior gelatinization will take a longer time than the substrate that has undergone gelatinization [24].

b) Liquefaction: Liquefaction is a process of hydrolysis of starch into smaller molecules such as maltose, glucose, and dextrins using the $\alpha$-amylase enzyme. Liquidation of starch is generally carried out until the dextrose equivalent reaches 15$20 \%$ or until the solution turns brick red when reacted with iodine solution [25]. The activity of the $\alpha$-amylase enzyme determines the rate at which the liquefaction process is slow. This enzyme will work faster when using a gel or gelatinized 
substrate [26]. liquefaction can be carried out at $105^{\circ} \mathrm{C}, \mathrm{pH} 6$ for 5 minutes or at $95-97^{\circ} \mathrm{C}, \mathrm{pH} 6$ for $1-3$ hours using thermostable $\alpha$-amylase. This $\alpha$-amylase enzyme breaks $\alpha$ $(1,4)$ glycosidic bonds randomly on the inside of the substrate and produces reducing sugars and dextrins with small amounts of glucose chains [27].

The $\alpha$-amylase enzyme is also called $\alpha$-retaining double displacement. The $\alpha$-amylase enzymes are divided into two groups, namely thermostable (heat resistant) and thermolable (not heat resistant). The thermostable $\alpha$-amylase enzymes can be obtained from Bacillus lichenoformis, Bacillus subtilis, Bacillus stearothermophilus and Bacillus amyloliquefaciens, whereas those which are thermolable are produced from fungi such as Aspergilus oryzae and Aspergilus niger [26]. Modified $\alpha$-amylase enzymes can work at temperatures up to $105-110^{\circ} \mathrm{C}$ with a $\mathrm{pH}$ range of 5.1-5.6 for 60-180 minutes [28]. Apart from being able to be obtained from microorganisms, $\alpha$-amylase enzymes are also found in many bean sprouts. The $\alpha$-amylase enzyme in seeds is formed during early germination by gibberilic acid [29].

c) Saccharification: Saccharification is an advanced hydrolysis stage after the liquefaction stage using the enzyme glucoamylase. Glucoamylase is one of the exoenzymes capable of hydrolyzing $\alpha-1,4$ bonds and a little $\alpha-1,6$ at the branching point. This enzyme will hydrolyze starch to oligosaccharides, matotriose to maltose and hydrolyze maltose to glucose [26]. Saccharification can be carried out at temperatures between $55-60^{\circ} \mathrm{C}$ with a $\mathrm{pH}$ of 4.5 where the process takes between 24-72 hours [30].

Glucoamylase (EC 3.2.1.3) is also known as amyloglucosidase or $\alpha$ - $(1,4)$-need glucohydrolase. Glucoamylase can be produced from fungi: Aspergillus spp, Rhizopus oryzae, Rhizopus niveus, from yeast: Saccharomycopsis fibuligera, Saccharomyces diasticus, and from bacteria: Clostridium acetobutylicum [31]. Glucoamylase produced from Aspergillus awanori and Aspergillus niger is classified as thermostable and has a more optimal $\mathrm{pH}$ range. Both microbes are now universally used for starch saccharification

To help the hydrolysis of the branching point, a specific enzyme is usually added, namely pullulanase. The combination of glucoamylase and pullulanase is often called the enzyme dextrozyme. Pullulanase (Pullulan 6-glucanohydrolase, EC 3.2.1.41) is an exoenzyme that catalyzes the hydrolysis of $\alpha-1$, 6-link pullulan and other polysaccharides to produce maltotriose as a final product. This enzyme can be obtained from extracts of rice and nuts [32]. Apart from plants, pullulanase can also be produced from mesophilic bacteria, such as Klebsiella, Escherichia coli, Streptococcus, Bacillus, and Streptomyces [33].

Enzymatic hydrolysis has several advantages, namely controllable process conditions, lower refining costs, less ash and by-products. In addition, the enzyme will break specific glycoside bonds, minimizing color damage and leaving no residue [34]. The results of research conducted by Virlandia
[35] state that the enzyme hydrolysis method is better than the acid hydrolysis method because the enzyme hydrolysis method has a value in accordance with the glucose syrup standard according to SNI

2) Acid hydrolysis: Acid hydrolysis can effectively break down the polymer into sugar monomers (arabinose, galactose, glucose, mannose and xylose). The temperature, time and acid concentration are used during the acid hydrolysis process. Some of the acids commonly used for acid hydrolysis include sulfuric acid (H2SO4), perchloric acid, and $\mathrm{HCl}$. Sulfuric acid is the acid most researched and utilized for acid hydrolysis. Acid hydrolysis can be classified into: concentrated acid hydrolysis and dilute acid hydrolysis [36]

a) Concentrated acid hydrolysis: Concentrated acid hydrolysis is a technique that has been developed for a long time. Concentrated acid hydrolysis yields high sugar (90\% of the theoretical yield) compared to dilute acid hydrolysis [37]. However, the hydrolysis process using this method requires a neutralization process which produces a lot of gypsum / lime waste. Adverse environmental impacts also result from this process. Apart from that, hydrolysis of concentrated acid also requires high investment and maintenance costs [36].

b) Dilute acid hydrolysis: Dilute acid hydrolysis is also known as two-stage acid hydrolysis (two stage acid hydrolysis) and is a method of hydrolysis that is widely developed and researched today. Dilute acid hydrolysis was first patented by H.K. Moore in 1919. The main advantages of hydrolysis with dilute acids are, no need for acid recovery, and no loss of acid in the process [38]. Generally, the acid used is $\mathrm{H} 2 \mathrm{SO} 4$ or $\mathrm{HCl}$. The downside of dilute acid hydrolysis is the formation of unwanted by-products.

The results of research conducted by Virlandia [35] stated, in the hydrolysis process using the acid method, the longer the hydrolysis process, the greater the reduction of sugar, but if it takes too long and the more acid is added, the reduction in reducing sugar levels occurs, this can be due to a browning reaction. or glucose dehydration.

\section{Purification}

In the production of sugar to produce good quality sugar, it's necessary to carry out a refining process. The refining is a process carried out to purify the starch produced by the milling process. Purification aims to separate impurities contained including soil, pulp, protein, wax, flour, fat, and substances that cause color and turbidity [39]. Based on research conducted by [40], it was explained that there are three types of sugar refining methods, namely defecation, sulfitation, and carbonation. The type of technology to be used will determine the level of color component absorption so that the resulting sugar product will be brighter and cleaner [41].

1) Defecation: The defecation process is only for making coarse granulated sugar. The defecation method is carried out by adding $\mathrm{Ca}(\mathrm{OH})_{2}$ in cold conditions until the solution 
becomes alkaline, then boiling until the dirt settles [42]. The advantages of this method are the low cost purification process and the resulting product is free from sulfur residues. Meanwhile, the weakness of defecation is the deposition is not good when compared to sulfitation and carbonation, so that the resulting sugar product is less uniform [39]. Defecation process is a purification process carried out by the addition of lime milk with a $\mathrm{pH}$ between $7,2-7,4$. This process is carried out on a defector that has a stirrer in it so that the solution becomes homogeneous [43].

2) Sulfitation: The method is able to bind dirt sulfitation more perfect than the methods of defecation, but it can still be improved by the method of carbonation. The sulfitation process is carried out by adding lime which is then neutralized with sulfur dioxide gas $\left(\mathrm{SO}_{2}\right)$. Lime water used in this process is much larger than the defication process [40]. The $\mathrm{CaSO}_{3}$ sediment that is formed can absorb colloidal particles around it, so that more dirt settles. $\mathrm{SO}_{2}$ gas has color whitening properties, so it is expected to produce sugar crystals with a lighter color. Sulfitation can be done in two ways, (1) Cold sulfitation: in this process $\mathrm{Ca}(\mathrm{OH})_{2}$ is added to the solution without heating it first. (2) Hot sulfitation: in this process it is heated at a temperature of $70-80^{\circ} \mathrm{C}$ and addition of $\mathrm{Ca}(\mathrm{OH})_{2}$ is carried out until it boils, then it is deposited. At about $75^{\circ} \mathrm{C}$, the solubility of $\mathrm{CaSO}_{3}$ is the lowest.

The advantages of this method are that the dirt is easier and settles quickly, the crystallization is better and the color of the resulting sugar is whiter. While the disadvantage of this method is that it requires a higher cost, because it is easy to corrode [39].

3) Carbonation: Carbonation has long been used in the refining process of raw sugar. This is a cheap and powerful process. The purification process involves adding the calcium hydroxide mixture to the raw aqueous solution. Then, carbon dioxide gas bubbles in the sugar solution in the saturator, under controlled $\mathrm{pH}$ and temperature conditions [44]. The process consists of adding lime milk (aqueous calcium hydroxide slurry) to melted raw sugar. The amount of lime is in the range $0.2 \%-0.8 \%$ of the sugar solid. Generally carbon dioxide is added to the saturator in two or three stages. The retention time varies from 45 minutes to 75 minutes, the $\mathrm{pH}$ of the sugar after leaving the final grain is between $8,2-8,5$. The impurities are absorbed by conglomerate calcium carbonate particles which are deposited by the reaction of carbon dioxide and calcium hydroxide [45].

The results of research conducted by [44] indicated that purification using a cleaner carbonation process, so that the resulting sugar products were whiter. Carbonation is very effective in refining sugar. About $40-50 \%$ of the color is removed and most of the turbidity (95\%), starch (93\%), sulfur $(86 \%)$ and phosphate $(100 \%)$ are removed. In the process of carbonation, most of the glucose, fructose and aconic acids are destroyed.

\section{Crystallization}

Crystallization is a series of steps in making sugar, through the process of forming solid crystals from a homogeneous solution, this process is very important because it produces a product with $100 \%$ purity. One method of crystallization is the addition of antisolvents and cooling [46]. If an organic solvent is mixed into a stirring solution in the form of sugar as an antisolvent, there will be dehydration of the sugar molecules. So that it will increase mobility in the content and facilitate the interaction between sugar and sugar. The result is easier nucleation and a higher crystal growth rate. The advantage of crystallization with the antisolvent method is that the crystallization process can be carried out at temperatures close to room temperature so that it is very beneficial for smaller substances than the solvent evaporation process $[47,48]$.

Crystallization with anti-solvent and refrigerant can use ethanol as an anti-solvent. The initial concentration of various fructose solutions was added with ethanol with different ethanol / solvent ratios and cooling rates. The stirring rate used was $500 \mathrm{rpm}$ and the final temperature was $30^{\circ} \mathrm{C}$. The crystal size and crystallization kinetics were calculated using the Nývlt method.

\section{CONCLUSION}

Arrowroot tuber have potential to be used as raw material for sugar production. The manufacture of sugar from arrowroot tuber through several stages, namely extraction, hydrolysis, purification and crystallization. Starch extraction can be done using wet or dry methods. Hydrolysis aims to break down starch into simple sugars which can be done by acid hydrolysis, enzymatic hydrolysis or a combination of both. Purification aims to remove impurities from sugar components through defecation, sulfitation, or carbonation methods. Crystallization aims to obtain sugar crystals which can be done by adding antisolvent or cooling. Productivity and quality of arrowroot starch-based crystal sugar depend on the sugar production method used.

\section{REFERENCES}

[1] Direktoral Jendral Perkebunan. 2019. Target Swasembada Gula Konsumsi jadi 2024. http://ditjenbun.pertanian.go.id/target-swasembadagula-konsumsi-jadi-2024

[2] Shahbandeh, M. 2020. Major sugar importing countries 2019/2020. https://www.statista.com/statistics/273438/principal-sugar-importingcountries/

[3] T. Bantacut, "Swasembada Gula : Prospek dan Strategi Pencapaiannya, "PANGAN, vol. 19, pp. 245-256, September 2010.

[4] Amalia, "Umbi Garut Sebagai Alternatif Pengganti Terigu Untuk Individual Autistik," Warta Penelitian Pengembangan Tanaman Industri, vol. 20(2), pp 20-31, 2014.

[5] T. F. Djaafar, Sarjiman, and A. B. Pustika, "Pengembangan Budi Daya Tanaman Garut dan Teknologi Pengolahannya untuk Mendukung Ketahanan Pangan,” Jurnal Litbang Pertanian, vol. 29, pp 25-33, 2010.

[6] H. Nurhayati, M. Yusron, Gusmaini, "Optimasi populasi tanaman garut (Maranta arundinaceae) di bawah tegakan tanaman perkebunan," Bogor (ID), Litbang Pertanian, 2007. 
[7] N. Setyowati, "Perbanyakan Garut \{Maranta arundinacea L.) dari Bibit Cabutan Sisa Panen dengan Aplikasi Berbagai Pupuk Kandang," PANGAN, vol. 21, pp. 389-396, Desember 2012.

[8] T. Handayani1, N. Wijayanto, and A. S. Wulandari, "Analisis Pertumbuhan Mindi (Melia Azedarach L) dan Produktivitas Umbi Garut (Maranta Arundinacea Dan Maranta Linearis L) Dalam Sistem Agroforestri," Jurnal Silvikultur Tropika, vol. 09, pp 144-150, Agustus 2018.

[9] Sarjiman, T.F. Djaafar, \& H. Purwaningsih, "Teknologi Budi Daya Garut Pada Lahan Pekarangan Untuk Meningkatkan Pendapatan Rumah Tangga di Lahan Marginal,” Prosiding Seminar Nasional Pengembangan

[10] Inovasi Pertanian Lahan Marginal, pp. 125-132, Juli 2007.

[11] B. Rudianto and R. Widarawati, "Upaya Peningkatan Kandungan Pati Umbi Garut dengan Perlakuan Bokhasi Dan Pengolahan Tanah," Agros, Vol.15, pp. 44-51, Januari 2013

[12] D. N. Faridah, D. Fardiaz, N. Andarwulan, T. C. Sunarti, "Karakteristik Sifat Fisikokimia Pati Garut (Maranta Arundinaceae)," AGRITECH, Vol. 34, pp. 14-21, Februari 2014

[13] Kementrian Kesehatan Republik Indonesia. 2019. Data Komposisi Pangan Indonesia. https://panganku.org/id-ID/view

[14] N. Setyowati, "Perbanyakan Garut \{Maranta arundinacea L.) dari Bibit Cabutan Sisa Panen dengan Aplikasi Berbagai Pupuk Kandang," PANGAN, vol. 21, pp. 389-396, Desember 2012

[15] Y. Marsono, "Indeks glisemik umbi-umbian," Makalah Seminar Nasional Industri Pangan Perhimpunan Ahli Teknologi Pangan Indonesia, Surabaya, Oktober 2002

[16] A. Ratna, F. Yulistiani, "Pembuatan Gula Cair dari Pati Singkong dengan Menggunakan Hidrolisis Enzimatis," Jurnal Fluida, Vol. 11, pp. 9-14, November 2015

[17] J. M. Cooper, "Sucrose," in Optimising Sweet Taste in Foods, 2006. https://www.sciencedirect.com/topics/agricultural-and-biologicalscience/sucrose

[18] J. D. Baker, "The Purpose, Process, and Methods of Writing a Literature Review," AORN Journal, Vol 103, pp. 265-269. March 2016.

[19] M. J. D. Paluga and A. M. M. Ragragio, "Th e Wet and the Dry Methods: Indigenous Technological Innovations in Palm Starch Extraction in the Central Philippines," 2016

[20] W S Ratnayake and D S Jackson, "Sources and Processing," in STARCH/Sources and Processing, University of Nebraska, pp. 566756672,2003

[21] M. N. Madineni, S. Faiza, R. S. Surekha, R. Ravi, and M. Guha, "Morphological, Structural, and Functional Properties of Maranta (Maranta arundinacea L) Starch,” Food Sci. Biotechnol, vol. 21, pp. 747-752, 2012

[22] G. F. Nogueiraa, F. M. Fakhourib, R.A. Oliveiraa, "Extraction and characterization of arrowroot (Maranta arundinaceae L.) starch and its application in edible films," Carbohydrate Polymers, vol 186, pp 64-72, 2018.

[23] L. M. Lubis, "Carbohydrate Polymers," Universitas Sumatera Utara, 2008

[24] T. F. Djaafar, S. Rahayu, Sarjiman, "Karakteristik rimpang garu (Marantha arundinacea) pada berbagai umur panen dan produk olahannya," Prosiding Seminar Nasional IPTEK Solusi Kemandirian Bangsa dalam Tahun Indonesia untuk Ilmu Pengetahuan, pp 23-28, 2006 .

[25] S. Mitsuiki, K. Mukaea, M. Sakai, M. Goto, S Hayashida, K. Furukawa, "Comparative Characterization of Raw Starch Hydrolizing a Amylase from Various Bacillus Strains.” J. Enzmic Tech, vol. 37, pp. 410-416, 2005.

[26] O. Misset, "Xylose (Glucose) Isomerase. In J.R. Whitaker., A.G.J. Voragen., and D.W.S. Wong" in Handbook of Food Enzymology. Marcell Dekker, Inc. New York, 2003.
[27] A.Y. Rahmawat, A. Sutrisno, "Hidrolisis Tepung Ubi Jalar Ungu (Ipomea Batatas L.) Secara Enzimatis Menjadi Sirup Glukosa Fungsional: Kajian Pustaka," Jurnal Pangan dan Agroindustri, Vol. 3, pp. 1152-1159, 2015.

[28] H. Norman, and Vang, "Enzymatic Preparation of Glucose Syrup from Starch," 2001. E. United State Patent, 2001

[29] S. Sivaramakrishnan, D. Gangadaran, K. M. Nampoothiri, C. R. Soccol, A. Pandey, " $\alpha$ Amylase From Microbial Sources An Overview on Recent Developments.," Journal of Food Technology and Biotechnology, vol 44, pp. 173-184, 2006.

[30] Suarni, and R. Patong, "Potensi Kecambah Kacang Hijau sebaga Sumber Enzim A-Amilase," Indo. J. Chem, vol 7, pp. 332-336, 2007

[31] T. Goodfrey and S. West, "Industrial Enzymology Second Edition," Macmillan Press Ltd. London, 1996.

[32] R. J. Reilly, "Glucoamylase," in J.R Whitaker AGJ Voragen and D.W.S. Wong (eds). Handbook of Food Enzymology. Marcell Dekker, Inc. New York, 2003

[33] L. Erianti, "Kajian Hidrolisis Pati Garut Menggunakan Enzim $\alpha$ Amilase dan Kombinasi Enzim a Amilase dan Pullulanase dalam Proses Produks Siklodekstrin," Jurnal Teknologi da Industri Pangan,XXII, 2011

[34] S. Gorinstein, C.G. Oates., Sh.M. Chang., and Ch.Yi. Lii, "Enzymatic Hydrolysis of Sago Starch," J. Food Chem, vol. 49, pp. 411-417, 1994

[35] F. Virlandia, "Pembuatan Sirup Glukosa dari Pati Ubi Jalar (Ipomea batatas) dengan Metode Enzimatis," 2008. http://andyafood.com

[36] C. Devita, W. Pratjojo W and Sedyawati, "Perbandingan Metode Hidrolisis Enzim Dan Asam Dalam Pembuatan Sirup Glukosa Ubi Jalar Ungu,” Indo. J. Chem. Sci. Vol. 4, 2015

[37] M. J. Taherzadeh, K.Karimi, K, "Enzyme-based Hydrolysis Processes for Ethanol from Lignocellulosics Materials: A Review." Bioresources, vol. 2, Pp. 707-738, 2007.

[38] Hamelinck, Hooijdonk, and Faaij, "Produksi Bioethanol Berbahan Baku Biomassa Lignoselulosa: Pretreatment" 2005

[39] J. Iranmahboob, F. Nadim, and S. Monemi, "Optimizing acidhydrolysis: a critical step for production of ethanol from mixed wood chips," Biomass and Bioenergy, vol. 22, pp. 401-404, 2002

[40] Y. Darni, L. Lismeri, Darmansyah. 2019. Industri Proses Kimia. Pustaka Media

[41] A. S. Latief, "Peningkatan Mutu Gula Tumbu Melalui Metode Sulfitasi," Laboratorium Gema Teknologi vol.16, pp. 40-48, April-Oktober 2010

[42] Sinuhaji dan Nirwan, "Analisis Pengolahan Tebu Menjadi Gula Kristal Putih Menggunakan Metode Fuzzy Logic Berbasis Matlab," Majalah Ilmiah Politeknik Bina Mandiri Bina Prestasi Vol 6, pp. 230-239, Desember 2017.

[43] Nurlela, "Pengaruh Penambahan Susu Kapur Untuk Memurnikan Keasaman Nira Tebu," Jurnal Media Teknik, Vol. 11, pp. 18-22, Januari-April 2014

[44] Hartanto, E. Sapto, "Peningkatan Mutu Gula Kristal Putih Melalui Teknologi Defekasi Remelt Karbonasi," Jurnal Standardisasi Vol.16 No.3, pp. 215-222, November 2014

[45] Moodley, "Optimising The Carbonatation Process." International Sugar Jurnal, pp. 469-476, 2002

[46] A. S. Vawda, A Comparative Evaluation of Carbonation and Phosphatation. SIT Paper 940, pp. 78-93, 2008.

[47] Hervelly, Y. Ikrawan, D. Mulyani, "Kajian Suhu Kristalisasi dan Konsentrasi Etanol pada Kristalisasi Molase yang Dijernihkan," Artike Kristalisasi Molase yang Dijernihkan Universitas Pasundan, pp. 1-9, 2016.

[48] M. Giulitte, and A. Bernardo, Crystallization by Antisolvent Addition and Cooling. Brazil: Chemical Engineering Department Federal University of Sāo Carlos UFSCar., pp. 279-296, 2012 